\title{
Transitional Justice in the Context of Ethiopia
}

\author{
Jima Dilbo Denbel \\ International Master in Peace, Conflict and Development Studies (PEACE Master) of \\ the Universitat Jaume I (UJI), Castellón, Spain \\ UNESCO Chair of Philosophy for Peace, \\ Tel +34964729380 \\ E-mail address: jdenbel@gmail.com, epd@uji.es
}

\begin{abstract}
Leadership and governance are very important aspects of living in any civilized society. It is however, imperative to note that leadership unfolds over time in different models, ideologies and approaches, by the different leaders. This gives connotation to the concept of transitional justice to ensure a smooth and meaningful change of power or leadership from one model or person to another to avoid despotism and anarchy. This paper debates the ideology of transitional justice and its focus on the subject of how societies should transit from authoritarian rule to democracy in order to address a persistent history of massive human rights abuses. This piece of work brings light on how societies across the world ought to deal with their evil pasts. The paper fronts Ethiopia as a case study to have an in-depth perspective of the trends and dynamics involved in transitional justice. The discussion is specifically limited on Ethiopia, focusing mainly on the transition which took place in 1991. The paper circumspectly handles key democratic issues in governance and in that respect shades light on what the concept of transitional justice is and its implications in governance and social relations of any country. It gives insights into how Ethiopia dealt with its past after the transition, discusses the lessons learnt, and the common alternatives always available to both government leaders and the populace in dealing with their past.
\end{abstract}

Keywords: Transitional justice; Democracy; Ethiopia; Authoritarianism; Transitional Government; Universalism

\section{INTRODUCTION}

The idea of transitional justice is as old as democracy. In ancient Athens, for instance, there were times when democracy was overthrown by oligarchy and oligarchy was also replaced by democracy. However, the return to democracy was associated with taking retributive measures against oligarchy (Elster, 2004, 3). In the last two decades, the concept of transitional justice has come to represent the midwife for a democratic, rule of law state. Furthermore, it is considered as an indispensable building block for sound constitutionalism, peace building, and national reconciliation in post conflict societies (Mutua, 2011, 31).

Since independence in the late 1950s and early 1960s, most African governments have been repressive and authoritarian. This has often been marked by serious violations of human rights. The attempts to move away from this dark era of dictatorship with the advent of the socalled "third wave" of democratization in the 1990s has been accompanied by numerous challenges, one of which is how to deal with the trauma and wounds of the past by ensuring 
that past human rights violations are accounted for in a manner that respects and protects the dignity of survivors and their relatives without threatening future peace and security. The democratization process has therefore also posed the problem of transitional justice. The movement from repressive to democratic systems of governance is a worldwide phenomenon and therefore the transitions in Africa have learnt from the inspiring experiences of other transitions in Central and Eastern Europe and also Latin America. The transitional challenges have usually been enormous. How do you deal with people who ruled on a daily basis by violence, terror, blackmail, intimidation and division? How do you bring back trust, economic prosperity, political stability and congenial social relations (Fombad, 2008)?

If we ask 'transition to what?' there would be many issues for discussion, since in some cases a new regime which has succeeded in over throwing the old one might continue the past repressions in a more subtle way and eventually there would be no transition at all. However, in this paper my discussion will be limited to the specific case of Ethiopia focusing mainly on the transition taken place in 1991. I am not going to discuss whether there is a genuine transition or not, since it is beyond the current topic. Nevertheless, since there was a transition that the country passed through which resulted in a change of regime, it would be fair to discuss how the transition was entertained.

Hence, the main focus of this piece of work is, mainly, embarking on how societies should deal with their evil pasts taking Ethiopia as a case study. What is transitional justice? How Ethiopia did deal with its past? What lessons are learnt? What alternatives are available in dealing with the past, if any? These are some of the major issue to be discussed.

\section{THE CONCEPT OF TRANSITIONAL JUSTICE}

Transitional justice focuses on the question of how societies transit from authoritarian rule to democracy and address a history of massive human rights abuses. It is concerned primarily with gross violations understood as torture, summary executions, forced disappearances, slavery and prolonged arbitrary detention, as well as certain international crimes, including genocide, crime against humanity and serious violations of the laws and customs applicable in armed conflicts, whether of national or international character (Patel, 2009, 249). However, as noted by Teitel, transition to democracy is, for some, characterized by free, fair and periodic election, for others, transition ends when all the politically significant groups accept rule of law $(2000,5)$, but what if these criteria were not fulfilled, could we say there is still transition for the mere fact that the old one is replaced by the new? Of course there is a transition at least from one regime to another. As I have noted earlier, I am not going to discuss the merits of transitions.

The term transitional justice consists of two notions. Firstly, temporary construction of post conflict society and secondly, as its name indicates it rejects a 'winner-take-all' approach. No one party or faction can be fully satisfied. But equally, it rejects impunity for the most hideous offenders. Hence, a balance must be struck between justice for victims and retribution against offenders (Mutua, 2011, 31-32). For Elster, transitional justice is made up of the processes of trials, purges, and reparations that take place after the transition from one political regime to another $(2004,1)$

The United Nations Secretary General's report on the rule of law and transitional justice in conflict and post conflict societies defined transitional justice as comprising: 


\begin{abstract}
The full range of processes and mechanisms associated with a society's attempts to come to terms with a legacy of large-scale past abuses, in order to ensure accountability, serve justice and achieve reconciliation. These may include both judicial and non- judicial mechanisms and individual prosecutions, reparations, truth-seeking, institutional reform, vetting and dismissal, or a combination thereof (United Nations, 2004, 4).
\end{abstract}

Therefore, it is worth while to study how to deal with our past so as to have a better future. We cannot abandon our past because it will always be with us. Since the future is largely a result of the past, constructing the future on the lessons of the past will help us not to repeat our previous mistakes (Mutua, 2011, 31-32).

In dealing with their past, with the aim of furthering peace, democracy and rule of law, it is essential to look for all the possible alternatives for post conflict societies rather than employing punishment through the due process of law. According to Teitel, despite the moral argument for punishment, there are various alternatives to punishment that could express the normative message of political transformation, the rule of law, and democracy $(2000,7)$. In general transitional justice aims at achieving justice in the aftermath of political transition by responding to sufferings from past and prevent similar sufferings from happening in the future (Lutz, 2006, 325).

\title{
3. THE CASE OF ETHIOPIA
}

\section{1. Historical Background of Atrocities in Ethiopia}

From 1930 until 1991, Ethiopia's history has been dominated by two individuals: Haile Selassie I, who became Emperor in 1930 and Mengistu Haile Mariam, who became the ruler after Haile Selassie, was overthrown in 1974. During Haile Selassie's rule, a growing tension grew between the various classes; he also attempted to introduce a fairer tax system but was frustrated in these attempts by the nobility and by landowners. He attempted to strengthen the national government and established a national judiciary. In 1955, a new constitution was drafted, but the bicameral Ethiopian government (parliament and Chamber of Deputies) played no role in its drafting. The constitution itself guaranteed personal freedoms and liberties, including due process of law (Sarkin 1999, 255).

Following the down fall of Emperor Haile Selassie I in 1974 Ethiopia fell under the military junta known as Derg $^{l}$, who ruled the country for the next 17 years. Soon after seizing power in September 1974, Derg suspended the constitution of the land and established a military government. Rejecting all calls for civilian rule, Derg began its brutality by executing 60 officials of the former imperial regime without court trial. Following this execution, the Derg was ruled by 'the law of the jungle' and was characterized by the most atrocious human right violations. In 1977, Derg executed hundreds of young people who planned a nationwide demonstration demanding civil government. According to eyewitnesses by May 1977 over 1000 young people had been executed. Derg's atrocities went beyond this. For instance, families who fortunately were able to identify the bodies of their murdered youth were requested to pay for the bullets that were used to kill their own sons and daughters before they claim the corpus (Girmachew, 2006, 65-66).

\footnotetext{
${ }^{1}$ Derg means 'committee' or 'council' in Geez language, a language that had been used by ancient Ethiopia mainly in the northern part of the country.
} 
In July 1977, over 1000 people were killed and 1,503 were arbitrarily detained of being a member of one or another political party. The worst came when the Red Terror was launched in November 1977 and lasted until 1980. According to some writers, it claimed the life of 30,000 to 50,000 people without court trial. Amnesty international reported that by the end of the red terror campaign, 150,000 to 200,000 people were executed (Girmachew, 2006, 66). Derg was finally overthrown after 17 years of brutal rule by the Ethiopian People's Revolutionary Democratic Front (EPRDF), in 1991. About 1,900 individuals were arrested of suspected of human right violations. The transitional government established a special prosecutor's office (SPO) to investigate and prosecute the massive human right violations of the Derg era (Girmachew, 2006, 67).

\section{2. Transitional Justice in Ethiopia}

Soon after seizing power, as a measure of transitional justice, the transitional government led by EPRDF established a special prosecutor's office (SPO) to prosecute and give justice for the victims and perpetrators of the seventeen year Derg rule. Why did the EPRDF choose this road? Why did they not set up a truth commission or other alternatives or hybrid approach (judicial and non-judicial) as in Rwanda or Sierra Leone?

Concerning the type of justice to be perused by the new regime, Sarkin noted the following:

The type of justice that is pursued is dependent on the type of transition of which there are three broad types: overthrow, reform and compromise. Being overthrown is the fate of a regime that has refused to reform: opposition forces become stronger and finally topple the old order. When reform is undertaken, the old government plays the critical role in the shift to democracy. In countries where change is the result of compromise, the existing regime and opposing forces are equally matched and cannot make the transition to democracy without each other. Such was the case in South Africa (Sarkin 1999, 253).

According to Sarkin, the case of Ethiopia falls under overthrow and the type of justice to be perused was at the hand of the winner and the Transitional Government of Ethiopia (TGE) chose the 'prosecution model' closing all other alternatives. The 'prosecution model' chosen by the TGE was believed to play a part in the healing of thousands of Ethiopians whose rights were violated during the terror of the Mengistu regime. However, experiences with other war crimes trials show that it is difficult to meet the hopes and expectations of the victims during such trials. Victims are mostly not involved in the trials, and are often denied the cathartic experience of a process that focuses on them as a victim (Sarkin 1999, 253-254).

The mandate given to SPO is to establish for public knowledge and for posterity a historical record of the abuses of the Mengistu regime and to bring those criminally responsible for human rights violations and/or corruption to justice. Since the SPO's mandate covers a broad scope, the SPO planned to try the detainees in three categories: urgent interim reparation, policy and decision makers, the field commanders - both military and civilian and the actual perpetrators of murder, torture and other crimes (Sarkin, 1999, 256-257).

\section{2. 1. Why the 'Prosecution Model' for Ethiopia?}

From the reading of the preamble of the proclamation establishing the office of the special prosecutor, proclamation No. $22 / 92$ one can fairly deduce that among many drives to 
employ the prosecution model the following could be worth mentioning. These are: bringing the perpetrators to trial so as to educate the people and make offenders aware of their heinous and horrendous offences to prevent recurrence of fascist rule of the previous government. The preamble of the proclamation gives a clue of political drives behind the establishment of the office of prosecution as well as reasons for bringing the perpetrators to justice. Eventually, the reason why the transitional government led by EPRDF chose this road might need further studies and deep analysis. However, according to Sarkin, the driving forces might be the following:

1. The incorporation of 'political groups' in the lists of genocide crimes in the criminal law (Penal code) of Ethiopia: The Ethiopian Penal Code incorporates rules of international customary law pertaining to genocide, crimes against humanity, and the breaches of the 1949 Geneva Conventions. As defined in the Genocide Convention, genocide consists of acts committed "With intent to destroy, a national, ethnical, racial or religious group". However, Article 281 of the Ethiopian Penal Code expands the scope of the targeted groups by incorporating 'political groups' in that list. This distinction is particularly important since the Red Terror was directed Mengistu's political enemies (Sarkin, 1999, 259).

2. At the time of the establishment of the SPO (1992), the use of international law as a basis for the prosecution of war crimes posed a fundamental problem. The offences of the Mengistu regime took place in an internal conflict, but it was not sure whether international customary law was applicable to those conflicts. Due to the perceived limitation of international rules, the only way to try the alleged perpetrators with war crimes was to charge them under the Ethiopian Penal Code that does not require war crimes to be committed in an international conflict (Sarkin, 1999, 259).

3. The use of domestic law offered another advantage in the eyes of the SPO: the death penalty. While under international law it is not clear whether a death sentence is possible, the Ethiopian Penal Code permits it for first-degree homicide, genocide, crimes against humanity and war crimes. Since the government did not want to exclude the death penalty for "the demands for justice from victims and their relatives" the choice of domestic law was necessary. In October 1995, the court turned down the request of the defendants that their trials be heard by an international tribunal (Sarkin, 1999, 259).

The prosecution model also has its own supporters. In this regard, Girmachew advocates retributive justice in cases of massive human right violations: He says, in cases of massive human rights violations, retributive justice is preferable and in such a case it the responsibility of the government to prosecute (Girmachew, 2006, 64).

At this juncture, it is worthwhile to mentions the underlying principles behind the employment of prosecution model in line with the place and space idea proposed by Wolfgang Sachs. While discussing the fundamental difference between universalism and localism, Sachs brings the idea of space and place in which he sheds light on the way universalism aspires to impose its space-centered idea on place-centered local cultures. According to him, the Universalist view characterizes numerous cultures as backward, deficient and meaningless, denying a space for local cultures as they are connected to particular places with their own particular peoples. On the other hand, the localist view seeks a place-centered idea by recognizing local cultures, where people share language and habits to constitute a particular style of being in the world (Sachs, 2010, 120-121).

The Ethiopian transitional justice system, I would say, became a victim of spacecentered universalism by ignoring place-centered local remedies, which could have served to 
keep harmonious relations among diverse communities. By employing a universally applicable and acceptable justice system the incumbent government may succeed in getting international recognition in spite of failure to bring reconciliation.

\section{2. 2. Prosecution model vis-à-vis transitional justice}

The following questions have to be answered while dealing with this issue. What are the objectives of transitional justice? Did the Ethiopian prosecution model serve the objectives of transitional justice? If the prosecution model has not served justice, what would be the possible options to meet these objectives? Whose interest has to be served in the process of transitional justice? What should be the role of the victims in such a case?

As noted by Sarkin, trials allow for recognition of only a single version of events. A truth commission, on the other hand, analyzes various versions of events and can validate more than one version by accepting differing testimony and incorporating all versions into a report which becomes official history. While trials can help lead to truth, the judicial system must adhere to principles of due process and assignment of individual, not collective, responsibility. Trials often limit truth discovery. The standards of proof for conviction in a criminal trial are higher than those that must be attained in a civil trial. Thus, guilty verdicts are far from certain. An acquittal can have a devastating effect on victims and the society in general. It must also be remembered that the aim of a trial is to attain a guilty verdict, not to assist victims in their recovery process. There could, therefore, be major failings and disadvantages in the use of the criminal justice system in a transitional for victims of human rights abuses (Sarkin, 1999, 254).

Furthermore, criminal sanctions are the revenge the society takes against the wrongdoers. Hence, it is not victim-centered. Even civil sanctions, which respond to the material loss of the victim, can not heal the inner wound of the victim (Mutua, 2011, 32).

If we see the performance of SPO in line with these critiques of the criminal justice system as a tool for transition periods, we can observe so many shortcomings. For instance, SPO began its process by hearing more than 2,500 witnesses and gathering more than 250,000 pages of documents, analyzing and entering these into computer databases. In October 1994, the SPO laid charges against the first perpetrators. At that time about 1,300 people were imprisoned. While the SPO had set targets to charge all defendants by 1994, this was not met. It was only at the end of 1996 that charges against 1,218 of the total 1,800 detainees were filed in Ethiopia's Federal High Court. In February 1997, it was announced that 5,198 persons had been charged with acts of genocide. A total of 2,246 were in detention, while the remaining 2,952 were charged in abstentia. However, it was only by 1998 that all alleged perpetrators had been indicted and arraigned (Sarkin, 1999, 262). Moreover as Fombad noted, the emphasis has been less on truth telling and more on the prosecution of those accused, and the recording of what happened (Fombad, 2008).

Furthermore, the courts in Ethiopia were understaffed. This is partly the result of the government's decision to remove dozens of experienced judges after assuming power. Thus, a severe shortage of trained personnel as well as financial limitations, limit the functioning of the judiciary. There are also resource constraints resulting in backlogs in the courts (Sarkin, 1999, 263).

All the trials have been characterized by years of delays. In 1999 many of the trials of the thousands of detainees were still being held up. As a result of these problems, defendants are sometimes being charged and tried collectively. Often the attorneys appointed by the courts were insufficiently skilled and As a result of the criticisms of these and other problems, many see these trials as being unfair and not leading to an impartial and objective result. The 
imposition of the death penalty has also affected support for the trials from outside. These fears played out when Mengistu was in South Africa in December 1999 and Human Rights Watch, citing concerns about the fairness of the Ethiopian trials, declined to press for Mengistu's return to Ethiopia. These groups suggested, however, that South Africa could try Mengistu before its own courts. Of great concern and of vital importance to victims is the fact that it is quite difficult to access information about the trials as little information or coverage is found in the media (Sarkin, 1999, 263).

If a goal is to provide to victims some closure, to hold people accountable for their crimes, this role is limited by the time it takes to hold such trials. The longer it takes, the more difficult it is for evidence to stand up to scrutiny, individual memory fades, and the interest of people wanes. The effect of such trials cannot have the resonance they would have had shortly after the transition to democracy. As the delays continue, public interest shifts to more immediate and pressing issues. Over time other political issues come to forefront. Experience also shows that, in general, trials often do not meet the hopes and expectations of victims. They are not often involved in the trial, and are often denied the healing experience of a process that focuses on them as victims, in isolation; trials allow for recognition of only a single version of events (Sarkin, 1999, 264).

Critically, in a society in transition, the courts are often composed of judges from the old order. Thus, their decisions may not be responsive to the needs of the new democratic order. If new judges have been appointed, they may not be willing to hand down decisions that are too politically controversial (Sarkin, 1999, 264). Here we can observe that in both cases, namely in assigning old or new judges, the interests of the victims were not considered. Instead, judges are either tilt to fulfil the interest of the new rule or lean to implement what the law demands.

Additionally, because of the standard of proof in a criminal trial is higher than that required in a civil one, guilty verdicts are far from certain. As Herman noted, punishing former political leaders does create anything to promote any positive vision of social reconstruction except creating a symbolic break of the old regime. It does nothing directly to restore the dignity of victims or to address the deeper corruption of relationships that permeates the society (Herman, 2000, 49 cited in Balatz, 2006, 61).

\section{2. 3. The Lost Opportunity}

While their case was on trial on 13 August 2004, 33 top former Derg officials wrote a letter to the Prime Minister of the country in seeking a forum where they can 'beg the Ethiopian public for their pardon for the mistakes they have done knowingly or unknowingly' (Girmachew, 2006, 67). The incumbent government did not give them the opportunity to do so.

Girmachew did not deny the contribution of apologies as a step towards for reconciliation that is needed in the country $(2006,82)$. His worry is the apology might be used as a tactical reason. However, he does not provide any evidence for the existence of such subtle interests on the side of the former officials. He rather argues that even though apology might have positive aspects it can not be accommodated by the trials because of the very nature of court proceedings. According to him, trials are mostly about ascertaining individual responsibility through the application of rules of law and presentation of relevant evidence. In law, the truth is a claim that is supported by evidence. Hence, the right to an effective remedy encompasses not only prosecution and investigation but also it encompasses duties to compensation, restitution, rehabilitation, satisfaction and guarantee of non-repetition on the part of the state (Girmachew, 2006, 82). 
If amnesty is not a trade-off for apology, does it bring legal liability on them when they admit to action? In law apology is not taken as an admission of facts because of the possibility of due influence. Although in other societies truth finding bodies have gathered relevant evidence for subsequent prosecution. In the case of Ethiopia, the question of amnesty or impunity was settled already when the government opted to investigate and prosecute the human right violations (Girmachew, 2006, 83). This argument is, actually, premature since the intention of the apology seekers have not been yet proven whether it was a tactical strategy for amnesty or an act of genuine confession for reconciliation.

Finally, Girmachew concluded if Derg officials are looking for a process where they can apologize to the public, while at the same time receiving exemption from liability, their request to apologize is hardly genuine. Apology does not automatically result in amnesty. Apology is essential in the remedial process. However, it should not be as a pretext to evade punishment and responsibility (Girmachew, 2006, 84). I hardly agree with such an argument because of the following two of reasons. Firstly, if apology does not automatically grant amnesty what would be the negative side of giving a forum for former suspects of human rights violators a chance to tell the facts, if not the truth, because of its controversy? Secondly, since the constitution and other subsidiary legislations of the country do not allow amnesty for genocide and crimes against humanity, I do not see any special benefits these former officials would get from such truth telling. I would rather argue that this was a lost opportunity for the Ethiopian people in general and for the perpetrators and victims in particular for it would contribute to the reconciliation and healing process eventually needed in the country.

Subsequently, I would agree apology should not be allowed to be a systematic strategy for amnesty without telling the facts and incidents of the time. However, if transitional justice is to heal the victims and restore relationships for the betterment of our common future, the perpetrators should not be denied at least to tell the truth to their knowledge or the facts of those evil times to the public as part of transitional justice. If we stick to the retributive aspect of justice, it somehow closes our eyes to see the other side of the historic episode.

Had the alleged perpetrators been allowed to tell the facts of those terrible times, we would have seen the other version of the time, which might have helped the victims to understand the political, social and economic situations of the time that led them and the status of mind that drove them to take such heinous measures and so many drives as of a rationale for committing those crimes. Since retributive or legal machineries are always at the hands of government, they can be employed any time as per the existing legislations. However, the restorative aspect of the process which would help the perpetrators and victims to heal their relationships and which, of course, brings lasting peace and development for the societies at large, would have been considered as a tool of fostering the transitions to democracies.

As John P. Lederach pointed out, "relationship is the basis of both conflict and its long term solution. Likewise, reconciliation is built on mechanisms that engage the sides of a conflict with each other as humans-in-relationship." (Lederach, 1997, 26). I would say Ethiopia missed the opportunity to integrate the human relations aspect so as to bring sustainable reconciliation rather than aiming solely at punishing perpetrates, which at end benefits no one.

As reported recently, among the 23 Derg higher officials, who were convicted for crimes against humanity and put into jail from life imprisonment to death penalty, 16 were released in October 2011 on parole (Reporter, 2011). This is happened actually, through the involvement of the religious leaders, but without providing favourable environments for reconciliation and healing. 


\section{2. 4. The Holistic Approach Model}

If the prosecution model is short of addressing the inner pain of the victims and fails to bring reconciliation, what alternatives would be available? Mutua suggests that if transitional justice systems are to have any hope of success in the tormented societies, a multi-cultural and all-inclusive perspective, or holistic approach, should be in place in crafting effective solutions to legacies of conflict (Mutua, 2011, 40). According to Mutua, a holistic approach to transitional justice has five pillars that combine accountability, truth, recovery, reconciliation, institutional reform and reparations in one ground package of social reclamation (Alex Boraine's, Cited in Mutua, 2011, 32). That is why the notions like ubuntu- the African philosophy of community wholesomeness - must be conceived as a new solution for the recovery of post-conflict societies (Mutua, 2011, 32). Here it is also worthwhile to mention the Gadaa system of conflict management of Oromo people of Ethiopia as an example of holistic approach that moves through different steps on its way to manage and resolve conflicts and arriving at Arara (reconciliation) so that harmonious relations can be restored among conflicting parties, God the creator, the community, and the surrounding world (Tuso, 2000,87 ). These ideas of local remedies also go with the place-centerd localism proposed by Sachs as I have noted earlier. Lederach also says reconciliation represents a place where the past and the future meet. It is also a space where past is acknowledged and future is envisioned, which also helps in reframing the present (Lederach, 1997, 27). Hence, in dealing with the past it would seem very important to focus on reconciliation so as to design a proper tool for a transition.

As UN basic principles on the use of restorative justice programmes in criminal matters indicates, transitional justice must move beyond the punitive to more restorative, comprehensive, and holistic transitional justice model. These principles are guided by their ability to heal, put victims at the center, seek cooperation with perpetrators before confrontation, understand abominations as injuries to social relations and achieve a community's commitment in reaching solutions. This approach requires the full participation of all assets of the community- traditional, ethical, CSOs, political and moral. This does not mean that this approach is pure and perfect. For instance, As Mutua indicated, truth commissions have naked limitations. Even the most famous one such as South Africa's - have still left a lot to be desired (Mutua, 2011, 41-42).

I consider arguments in favour of the holistic approach which allows the involvement of all concerned parties mainly the perpetrators and victims as it helps us to see the context or the root cause of the situation and seek proper transformative solutions to the present problem, and as well as draw durable lessons for the future. Hence, giving a forum for perpetrators to tell the facts of those evil past days would be helpful in understanding the context and the drives behind those atrocities. Moreover, it assists us to learn from our past mistakes and shows us a way we can avoid similar mistakes in the future.

As Lederach points out, to bring a constructive changes within a society the best approach is going beyond the resolution of specific problems and focuses toward building healthy relationship among communities, locally and globally, which he calls 'Conflict transformation' as an alternative to 'Conflict resolution' (Lederach, 2003, 4-5).

\section{CONCLUSIONS}

As I have tried to explore in this short piece of work, the nature of the transition plays a major role in determining how human rights violations of the past will be dealt with. There 
are various models that a new state can use to deal with an atrocious history of human rights abuse. A common thread is the desire to pave the way for a future peaceful and democratic society. Therefore, rather than running after prosecution of the perpetrators it would be recommendable to consider the interests of the victims and of the community at large (Sarkin, 1999, 253).

In choosing proper models, countries should employ a model which is all-inclusive and aims at bringing transformative change within the society and imprint a profound lesson for the present and coming generation so that the recurrence of such violations would be minimized, if not eliminated. Criminal trials are not sufficient to bring reconciliation and healing for the victims. Therefore, I denote the request of the former government officials for apology as 'a missed opportunity'. Had the current regime allowed them to tell the truth, to their knowledge by their own free will, rather than sticking only to rigorous imprisonment or death penalty, it would have resulted in healing the for victims. Moreover, the recent release of top officials from prison by pardon may instigate more anger and act of revenge since nothing has done so far for reconciliation. Finally, I favour a holistic and all-inclusive approach to transitional justice, which intends to bring transformative change and concerns about reconciliation and human relationships as opposed to stringent approach of ordinary legal machineries.

\section{References}

[1] Blatz V. Charles, "Reason, peace, Transitional Justice, and Punishment". International Journal of peace studies 11(1) (2006) 59-89.

[2] Elister Jon, Closing the books: Transitional Justice in Historical Perspectives, Cambridge University Press, 2004.

[3] Ethiopian Penal Code, 1957. Available at: http://www.unhcr.org/refworld/pdfid/4921 6a0a2.pdf [Accessed on 11 Nov. 2011]

[4] Fombad, Charles Manga, Transitional Justice in Africa. The Experience with Truth Commissions, 2008.

http://www.nyulawglobal.org/globalex/ Africa Truth Commissions. htm [Accessed on 11 Nov. 2011]

[5] Girmachew, Alemu Aneme, "Apology and trials: The case of the red terror trials in Ethiopia”. African Human Rights Law Journal 6(1) (2006).

[6] Hamdesa Tuso, "Indigenous Processes of Conflict Resolution in Oromo Society" in I. William Zartman. ed., Traditional Cures for “Modern Medicine” Lynne Rienner Publishers, 2000.

[7] Lederach, John Paul, The little book of Conflict transformation, Good Books intercourse, PA, USA, 2003.

[8] Lederach, John Paul, Building peace; Sustainable reconciliation in divided societies, United States Institutes Of peace Studies, Washington D.C, 1997.

[9] Lutz, Ellen, "Transitional justice: Lessons learned and road ahead", in Arriaza and Mariezcurrena (eds), Transitional justice in the twenty-first century: beyond truth versus Justice, Cambridge University press, 2006. 
[10] Matua, Makau, "A critique of rights in transitional Justice: An African experience" in Aguilar and Gomez Isa (Eds.). Rethinking transitions: equality and social justice in societies emerging from conflict, Series on Transitional Justice No.6, Cambridge UK, 2011.

[11] Patel, Ana Cutter, "Transitional Justice and DDR" in Muggah, Rubert(ed.): Security and Post-conflict Reconstruction: Dealing with the fighters in the Aftermath of War, New York, USA, 2009? Taylor \& Francis e-Library (2008) Routledge (2009).

[12] Proclamation No. 22, Special public prosecutor's office establishing proclamation; 1992. http://www.usip.org/files/resources/Ethiopia-Charter.pdf

[Accessed on 11 Nov. 2011]

[13] Sachs Wolfgang, "One world" in Wolfgang Sachs (eds.) The development dictionary: A guide to Knowledge as power (pp.111-125), Zed Books 2010.

[14] Sarkin Jeremy, "Transitional justice and the Prosecution model: The experience of Ethiopia”. Journal of Law, Democracy and Development 3(20) (2011) 252-266, University of the Western Cape', 1999. Available at:

http://www.ldd.org.za/images/stories/Ready_for_publication/V32_Transitional_justice_ prosecution_model.pdf

[accessed on 14 Nov, 2011].

[15] Teitel, Ruti G., Transitional Justice, Oxford University press, New York, 2000.

[16] The Reporter, Derg officials released from Jail, 2011. http://www.thereporterethiopia.com/News/derg-officials-released-from-jail.html [Accessed on 11 Nov. 2011].

[17] United Nations, Report of the Secretary-General on the Rule of Law and Transitional Justice in Conflict and Post-Conflict Societies, UN doc. (S/616), 2004. http://daccess-dds-ny.un.org/doc/UNDOC/GEN/N04/395/29/PDF/N0439529.pdf? Open Element

[Accessed on 11 Nov. 2011] 